\title{
Retraction Note to: Influence of crumb rubber particle sizes on rutting, low temperature cracking, fracture, and bond strength properties of asphalt binder
}

\author{
Jiandong Huang • Qi-Ang Wang
}

Published online: 23 February 2022

(C) RILEM 2022

\section{Retraction Note to:}

Materials and Structures (2021) 54:1-15

https://doi.org/10.1617/s11527-021-01647-4

The Editor-in-Chief has retracted this article upon request of the authors because of a dispute over the ownership of some of the data and text presented here. All authors agree to this retraction.

Publisher's Note Springer Nature remains neutral with regard to jurisdictional claims in published maps and institutional affiliations.

The original article can be found online at https:// doi.org/10.1617/s11527-021-01647-4.

J. Huang

School of Mines, China University of Mining and

Technology, Xuzhou 221116, China

Q.-A. Wang ( $ه)$

State Key Laboratory for Geomechanics and Deep Underground Engineering \&, School of Mechanics and Civil Engineering, China University of Mining and Technology, Xuzhou 221116, China

e-mail: qawang@cumt.edu.cn 